\title{
BEHAVIOR OF SELF-COMPACTING CONCRETE USING PPC AND OPC WITH DIFFERENT PROPORTIONS OF FLY ASH
}

\author{
Mohammad Kamran', Mudit Mishra ${ }^{2}$ \\ ${ }^{1}$ Student, Department of Civil Engineering, Jamia Millia Islamia, Jamia Nagar, New Delhi, India \\ ${ }^{2}$ Assistant Professor, Department of Civil Engineering, Manav Rachna International University, Delhi Surajkund \\ Road, Aravalli Hills, Faridabad, Haryana, India
}

\begin{abstract}
Self compacting concrete has been playing vital role in the mass concreting nowadays especially in the structures where reinforcement used is very dense and in narrow tubular sections. This paper talks about its comparison in behavior using PPC and OPC with different proportions of fly ash in the mix which were taken as 15\%, 25\%, and 35\% in place of cement. For one proportion, a set of 6 cubes was casted and the same was to be tested at 7 days and 28 days for strength. The temperature of sample cubes was kept constant at $24^{\circ} \mathrm{C}$ for the whole period. The mix design was done for M25 grade. The W/C ratio was kept constant at 0.45. The proportion of fine aggregates to coarse aggregates was kept at 70:30 and maximum size of aggregates was $20 \mathrm{~mm}$. Total powder content was kept at $530 \mathrm{Kg} / \mathrm{m}^{3}$. The quantity of super plasticizer was kept at $450 \mathrm{ml}$ for the samples which was $1 \%$ of the total volume. The properties were checked by conducting slump test, J-Ring Test, L-Box Test, V-funnel Test, and UBox Test with compressive strength test after 7 days and 28 days. The slump value was maximum for $35 \%$ replacement of cement with fly ash and lowest for 25\% replacement in PPC mix whereas in OPC mix this value increased with increasing proportion of fly ash. V-funnel value was decreasing in both cases with increasing proportions of fly ash. J-ring value was highest for $25 \%$ replacement in both cases. U-box value was maximum for $25 \%$ replacement in both cases and showed almost the same trend. Lbox value was lowest for $25 \%$ replacement in both cases and showed the same trend as in U-box test. The most important compressive strength test showed very surprising results. Only 15\% replacement samples showed characteristic strength after 7 and 28 days whereas $25 \%$ replacement samples gained only 55\% of desired strength and 35\% replacement samples gained only $33 \%$ of desired strength after 7 days and gained $92 \%$ and $80 \%$ of desired strength after 28 days respectively in PPC samples. The similar tests conducted on OPC samples showed the same pattern but overall strength gain was higher than PPC samples and the margin was spectacularly high ranging between $40 \%-60 \%$.
\end{abstract}

Keywords: Self Compacting Concrete, Fly Ash, V-Funnel, Slump Value, Compressive Strength

\section{INTRODUCTION}

Self-compacting concrete (SCC) has been described as "the most revolutionary development in concrete construction for several decades"(efnarc,2002). Self compacting concrete, a recent innovation has numerous advantages over conventional concrete. it can spread and fill all corners by means of itself weight only, thus eliminating the need of vibration for any type of consolidation effort[1]. originating in Japan[2] with a view to reduce the reliance on skilled workers and to enhance productivity of construction without compromising quality of concrete[3]. also known as self consolidating concrete, super workable concrete, no vibrating concrete[4]. It is flow able and deformable without segregation[1,4]. In order to maintain deformability along with flow ability in paste, a super plasticizer is an indispensable ingredient for such concrete.

SCC typically has a higher content of fine particles and different flow properties than conventional plasticized concrete. It should have three essential properties: filling ability, resistance to segregation and passing ability. the mixture proportioning is based on creating a high degree of flow ability while maintaining a low w/c ratio. This is achieved by using water reducing admixture combined with stabilising agents such as viscosity modifying admixture to ensure homogeneity of mixture for reasons of achieving better rheological properties, reduction in cost, increase in powder content. A high amount of mineral admixture is typically used. Use of fly ash GGBFS, limestone powder increases fine materials in a concrete mixture[1]

Self compacting concrete can be used in different components of structure even combined with narrow tubular sections. It was done by using different proportions of fly ash at constant temperature condition to see the settling by performing different tests on the samples first by using PPC and then by using OPC as main pozzolanic material.

Generally PPC is an obvious choice for concrete mixes nowadays whereas OPC is being outdated despite showing better results because of financial aspects but selection was to be made between the two to see its behaviour in the manufacturing of SCC[7].

\section{EXPERIMENTAL STUDY}

Self compacting concrete with constant w/c ratio and quantity of super plasticizer $(1 \%)$ was prepared as per the mix design for both the cases. The percentage of $20 \mathrm{~mm}$ aggregate was $30 \%$ and that of fine aggregate was $70 \%$. The total powder content was kept constant equal to $530 \mathrm{Kg} / \mathrm{M}^{3}$ 
in all the trials. Thereafter, to check the effects on strength of SCC, more percentage of fly ash mixed by replacing the quantity of cement by $15 \%, 25 \%$ and $35 \%$. The w/c ratio of 0.45 was kept constant. For each concrete mix, 6 cubes of sizes $150 \times 150 \times 150 \mathrm{~mm}$ were casted to determine the compressive strength. After casting, the specimens were cured in water tub for 7 days at room temperature. Three out of them were then tested after 7 days compressive strength of SCC and the rest were tested on 28 days. The following tests were conducted to check the specified properties of the concrete sample prepared.

Slump flow test: Primarily to assess filling ability, suitable for laboratory and site use.

U-Box test: The test is used to measure the filling ability of self compacting concrete.

L-box test: The L-box test is used to assess the passing ability of self-compacting concrete to flow through tight openings including spaces between reinforcing bars and other obstructions without segregation or blocking.

V-funnel test: The V-funnel test is used to assess the viscosity and filling ability of self-compacting concrete.

J-ring test: Primarily to assess filling ability, suitable for laboratory and site use.

Compressive strength test: The compressive strength of concrete was measured using AIMIL compression testing machine with a loading capacity of $2000 \mathrm{KN}$ confirming to IS: 14858 (2000). The compressive strength test was carried out on cubes at the 7 and 28 days.

\section{OBSERVATIONS}

\section{Samples with PPC}

Sample 1: Mix with $15 \%$ fly ash of total powder was prepared as shown in the table 1:

Sample 2: Mix with $25 \%$ fly ash of total powder was prepared as shown in the table 1:

Sample 3: Mix with 35\% fly ash of total powder was prepared as shown in the table1:

Table 1: Mix Design for Sample 1, Sample 2, Sample 3

\begin{tabular}{|c|c|c|c|}
\hline \multicolumn{2}{|l|}{ Temp: $24{ }^{\circ} \mathrm{C}$} & \multicolumn{2}{|c|}{ w/c ratio: 0.45} \\
\hline & $\begin{array}{ll}15 \% & \text { Fly } \\
\text { Ash } & \end{array}$ & $\begin{array}{ll}25 \% & \text { Fly } \\
\text { Ash } & \end{array}$ & $\begin{array}{ll}35 \% & \text { Fly } \\
\text { Ash } & \end{array}$ \\
\hline Components & & & \\
\hline Cement (Kg) & 20.05 & 17.8 & 15.35 \\
\hline Fly Ash(Kg) & 3.53 & 5.78 & 8.23 \\
\hline $\begin{array}{l}\text { Fine } \\
\text { aggregate }(\mathrm{Kg})\end{array}$ & 38.53 & 38.53 & 38.53 \\
\hline $\begin{array}{l}\text { C.Aggregate } \\
20 \mathrm{~mm}(\mathrm{Kg})\end{array}$ & 12.46 & 12.46 & 12.46 \\
\hline $\begin{array}{l}\text { C.Aggregate } \\
10 \mathrm{~mm}(\mathrm{Kg})\end{array}$ & 23.14 & 23.14 & 23.14 \\
\hline Water (lit.) & 10 & 10 & 10 \\
\hline $\begin{array}{l}\text { Super } \\
\text { plasticiser } \\
\text { (ml.) }\end{array}$ & 450 & 450 & 450 \\
\hline
\end{tabular}

The various properties of the mix were observed as tabulated in table 2:
Table 2: Different Properties of Mix

\begin{tabular}{|l|l|l|l|l|}
\hline Test & $\begin{array}{l}15 \% \text { Fly } \\
\text { Ash }\end{array}$ & $\begin{array}{l}25 \% \text { Fly } \\
\text { Ash }\end{array}$ & $\begin{array}{l}35 \% \text { Fly } \\
\text { Ash }\end{array}$ & Range \\
\hline $\begin{array}{l}\text { Slump } \\
\text { flow }\end{array}$ & $630 \mathrm{~mm}$ & $610 \mathrm{~mm}$ & $670 \mathrm{~mm}$ & $\begin{array}{l}550-800 \\
\mathrm{~mm}\end{array}$ \\
\hline Time & $4.23 \mathrm{sec}$ & $3.2 \mathrm{sec}$ & $5 \mathrm{sec}$ & $2-5 \mathrm{sec}$ \\
\hline V-Funnel & $10 \mathrm{sec}$ & $10 \mathrm{sec}$ & $7.45 \mathrm{sec}$ & $7-12 \mathrm{sec}$ \\
\hline J-ring & $6 \mathrm{sec}$ & $7.50 \mathrm{sec}$ & $6.6 \mathrm{sec}$ & $4-8 \mathrm{sec}$ \\
\hline $\begin{array}{l}\text { J-ring } \\
\text { flow }\end{array}$ & 580 & 600 & 630 & $500-700$ \\
\hline U-box & $27 \mathrm{~mm}$ & $30 \mathrm{~mm}$ & $28 \mathrm{~mm}$ & $<30 \mathrm{~mm}$ \\
\hline L-box & 0.82 & 0.789 & 0.85 & $0.8-1.0$ \\
\hline
\end{tabular}

The most important property was checked by performing compressive strength test on samples and calculated data is shown in table 3:

Table 3: Compressive strength of samples at 7 days and 28

\begin{tabular}{|c|c|c|c|c|c|c|c|}
\hline \multicolumn{8}{|c|}{ days } \\
\hline & Cube & 1 & 2 & 3 & 4 & 5 & 6 \\
\hline & Days & 7 & 7 & 7 & 28 & 28 & 28 \\
\hline \multirow{3}{*}{$\begin{array}{l}15 \% \text { Fly } \\
\text { Ash }\end{array}$} & Comp & 16. & 16. & 16. & 27. & 28. & 27. \\
\hline & $\begin{array}{l}\text { Streng } \\
\text { th } \\
(\mathrm{MPa})\end{array}$ & 25 & 80 & 11 & 33 & 12 & 66 \\
\hline & $\begin{array}{l}\text { Avg } \\
\text { Streng } \\
\text { th } \\
(\mathrm{MPa})\end{array}$ & \multicolumn{3}{|c|}{16.34} & \multicolumn{3}{|c|}{27.70} \\
\hline \multirow{3}{*}{$\begin{array}{l}25 \% \text { Fly } \\
\text { Ash }\end{array}$} & Comp & 9.2 & 10. & 9.7 & 24. & 24. & 24. \\
\hline & $\begin{array}{l}\text { Streng } \\
\text { th } \\
(\mathrm{MPa})\end{array}$ & 88 & 2 & 3 & 27 & 46 & 12 \\
\hline & $\begin{array}{l}\text { Avg } \\
\text { Streng } \\
\text { th } \\
\mathrm{MPa}\end{array}$ & \multicolumn{3}{|l|}{9.74} & \multicolumn{3}{|c|}{24.28} \\
\hline \multirow{3}{*}{$\begin{array}{l}35 \% \text { Fly } \\
\text { Ash }\end{array}$} & Comp & 5.4 & 5.8 & 4.9 & 21. & 21. & 21. \\
\hline & $\begin{array}{l}\text { Streng } \\
\text { th } \\
(\mathrm{MPa})\end{array}$ & 5 & 1 & 1 & 56 & 33 & 94 \\
\hline & $\begin{array}{l}\text { Avg } \\
\text { Streng } \\
\text { th } \\
(\mathrm{MPa})\end{array}$ & \multicolumn{3}{|c|}{5.39} & \multicolumn{3}{|c|}{21.61} \\
\hline
\end{tabular}

\section{Samples with OPC}

Sample 4: Mix with $15 \%$ fly ash of total powder was prepared as shown in the table 4:

Sample 5: Mix with $25 \%$ fly ash of total powder was prepared as shown in the table 4:

Sample 6: Mix with 35\% fly ash of total powder was prepared as shown in the table4: 
Table 4: Mix Design for Sample 4, Sample 5, Sample 6

\begin{tabular}{|c|c|c|c|}
\hline \multicolumn{2}{|l|}{ Temp: $24^{\circ} \mathrm{C}$} & \multicolumn{2}{|c|}{ w/c ratio: 0.45} \\
\hline & $\begin{array}{l}15 \% \quad \text { Fly } \\
\text { Ash }\end{array}$ & \begin{tabular}{ll|}
$25 \%$ & Fly \\
Ash &
\end{tabular} & $\begin{array}{ll}35 \% & \text { Fly } \\
\text { Ash } & \end{array}$ \\
\hline Components & & & \\
\hline Cement (Kg) & 20.05 & 17.8 & 15.35 \\
\hline Fly Ash(Kg) & 3.53 & 5.78 & 8.23 \\
\hline $\begin{array}{l}\text { Fine } \\
\text { aggregate }(\mathrm{Kg})\end{array}$ & 38.53 & 38.53 & 38.53 \\
\hline $\begin{array}{l}\text { C.Aggregate } \\
20 \mathrm{~mm}(\mathrm{Kg})\end{array}$ & 12.46 & 12.46 & 12.46 \\
\hline $\begin{array}{l}\text { C.Aggregate } \\
10 \mathrm{~mm}(\mathrm{Kg})\end{array}$ & 23.14 & 23.14 & 23.14 \\
\hline Water (lit.) & 10 & 10 & 10 \\
\hline $\begin{array}{l}\text { Super } \\
\text { plasticiser } \\
\text { (ml.) }\end{array}$ & 450 & 450 & 450 \\
\hline
\end{tabular}

Table 5: Different Properties of Mix

\begin{tabular}{|l|l|l|l|l|}
\hline Test & $\begin{array}{l}15 \% \text { Fly } \\
\text { Ash }\end{array}$ & $\begin{array}{l}25 \% \text { Fly } \\
\text { Ash }\end{array}$ & $\begin{array}{l}35 \% \text { Fly } \\
\text { Ash }\end{array}$ & Range \\
\hline $\begin{array}{l}\text { Slump } \\
\text { flow }\end{array}$ & $622 \mathrm{~mm}$ & $627 \mathrm{~mm}$ & $680 \mathrm{~mm}$ & $\begin{array}{l}550-800 \\
\mathrm{~mm}\end{array}$ \\
\hline Time & $4.41 \mathrm{sec}$ & $3.46 \mathrm{sec}$ & $4 \mathrm{sec}$ & $2-5 \mathrm{sec}$ \\
\hline V-Funnel & $9 \mathrm{sec}$ & $8.5 \mathrm{sec}$ & $7.45 \mathrm{sec}$ & $7-12 \mathrm{sec}$ \\
\hline J-ring & $6 \mathrm{sec}$ & $7.50 \mathrm{sec}$ & $6.6 \mathrm{sec}$ & $4-8 \mathrm{sec}$ \\
\hline $\begin{array}{l}\text { J-ring } \\
\text { flow }\end{array}$ & 595 & 600 & 620 & $500-700$ \\
\hline U-box & $27.5 \mathrm{~mm}$ & $30 \mathrm{~mm}$ & $28 \mathrm{~mm}$ & $<30 \mathrm{~mm}$ \\
\hline L-box & 0.82 & 0.789 & 0.9 & $0.8-1.0$ \\
\hline
\end{tabular}

Table 6: Compressive strength of samples at 7 days and 28

\begin{tabular}{|c|c|c|c|c|c|c|c|}
\hline \multicolumn{8}{|c|}{ days } \\
\hline & Cube & 1 & 2 & 3 & 4 & 5 & 6 \\
\hline & Days & 7 & 7 & 7 & 28 & 28 & 28 \\
\hline \multirow{3}{*}{$\begin{array}{l}15 \% \mathrm{~F} \\
\text { lyAsh }\end{array}$} & Comp & 19. & 18. & 18. & 34. & 33. & 34. \\
\hline & $\begin{array}{l}\text { Strength } \\
\text { (MPa) }\end{array}$ & 00 & 80 & 58 & 53 & 67 & 16 \\
\hline & $\begin{array}{l}\text { Avg } \\
\text { Strength } \\
\text { (MPa) }\end{array}$ & \multicolumn{3}{|c|}{18.79} & \multicolumn{3}{|c|}{34.12} \\
\hline \multirow{3}{*}{$\begin{array}{l}25 \% \mathrm{~F} \\
\text { lyAsh }\end{array}$} & Comp & 12. & 13. & 12. & 28. & 27. & 29. \\
\hline & $\begin{array}{l}\text { Strength } \\
\text { (MPa) }\end{array}$ & 88 & 10 & 50 & 27 & 46 & 12 \\
\hline & $\begin{array}{l}\text { Avg } \\
\text { Strength } \\
\text { MPa }\end{array}$ & \multicolumn{3}{|c|}{12.82} & \multicolumn{3}{|c|}{28.28} \\
\hline \multirow{3}{*}{$\begin{array}{l}35 \% \mathrm{~F} \\
\text { lyAsh }\end{array}$} & Comp & 8.7 & 8.1 & 9.8 & 23. & 24. & 23. \\
\hline & $\begin{array}{l}\text { Strength } \\
\text { (MPa) }\end{array}$ & 6 & 0 & & 56 & 13 & 94 \\
\hline & $\begin{array}{l}\text { Avg } \\
\text { Strength } \\
\text { (MPa) }\end{array}$ & \multicolumn{3}{|c|}{8.886} & \multicolumn{3}{|c|}{23.89} \\
\hline
\end{tabular}

\section{RESULTS AND DISCUSSIONS:}

- The experimental study showed that the only change in the mix lied with quantity of cement and fly ash, so the results were dependent on the compatibility of these two matters with each other. The type of cement that was used belonged to PPC which has some percentage of fly ash already in the composition and OPC which has purely cement without any addition of pozzolanic admixtures . Any addition in fly ash content was going to result in even higher percentage of the same actually present in the mix.

- The observations showed that the results were always within permissible range, anytime in any mix, the critical value was not exceeded. Though the results of different tests on OPC and PPC showed different trends and patterns. The results were randomly varied for different experiments and different proportions.

- $\quad$ The compressive strength results of PPC sample showed that after 7 days, the mix with least fly ash content gained maximum strength which was desired as per $67 \%$ of total characteristic strength. The remaining samples gained very less strength in first 7 days but started gaining after this time to 28 days time mainly because of secondary hydration of lime which generally occurs in fly ash but the overall strength gained even after 28 days was maximum with least fly ash percentage content than the rest. So it can be deduce that quantity of fly ash should be kept around $15 \%$ of total powder content in the given temperature and atmospheric conditions at the above specified $\mathrm{w} / \mathrm{c}$ ratio whereas the compressive strength results of OPC samples also showed that after 7 days and 28 days ,the mix with least fly ash content gained maximum strength but the average strength of OPC samples was much higher than that of PPC samples in each proportions of fly ash and the physical features of PPC samples showed the evolvement of superplasticizers and moisture on samples which results in reduction in strength whereas the samples casted with OPC were dried and no moisture developed over the surface of the samples and hence gave higher strength.

\section{REFERENCES}

[1]. H. Okamura, Self-compacting high performance concrete, ACI Concr Int, 19 (7) (1997), pp. 50-54

[2]. J.M. Campion, P. Jost, Self-compacting concrete: expanding the possibility of concrete design and placement, ACI Concr Int, 2 (4) (2000), pp. 31-34

[3]. K.W. Day, Concrete mix design, quality control and specification, Taylor \& Francis, New York (2006)

[4]. M. Kurita, T. Nomura, High-flowable steel fiberreinforced concrete containing fly ash, V.M. Malhotra (Ed.), Proceedings of the sixth CANMET/ACI international conference on fly ash, silica fume, slag, and natural 
pozzolans in concrete, SP-178, American Concrete Institute, USA (1998), pp. 159-179

[5]. A Skarendahl, Ö Petersson,Self-compacting concrete, ̊ Skarendahl, Ö Petersson (Eds.), State-of-the-art report of RILEM Technical Committee 174-SCC self-compacting concrete, RILEM, Cachan Cedex, France (2001), pp. 25-39 [6]. Bartos PJM. Measurement of key properties of fresh self-compacting concrete. In: Proceeding of CEN/STAR PNR workshop on measurement, testing and standardization: future needs in the field of construction materials. Scotland: University of Paisley; 2000. (27.04.03). [7]. http://www.differencebetween.net/object/differencebetween-opc-and-ppc/

\section{BIOGRAPHIES}

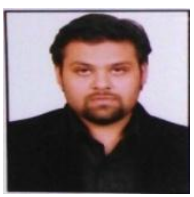

Name: Mohammad Kamran1

Pursuing $M$ Tech in Earthquake Engineering, Jamia Millia Islamia, New Delhi, India

Contact no: $+91-8447223179$

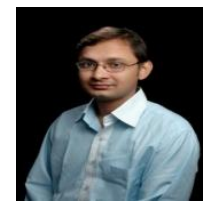

Name: Mudit Mishra

Assistant Professor at Manavrachna International University, Faridabad, Haryana, India

Contact no: $+91-9971898822$ 